OPEN ACCESS

Edited by:

Dylan Craven,

Universidad Mayor, Chile

Reviewed by:

Sahadev Sharma,

University of Malaya, Malaysia

Alexander Tischer,

Friedrich Schiller University Jena,

Germany

Beate Michalzik

Friedrich Schiller University Jena,

Germany

Jorge Andres Ramirez,

University of Cauca, Colombia

${ }^{*}$ Correspondence:

Alan M. Tonin

tonin.alan@gmail.com

Specialty section:

This article was submitted to

Tropical Forests,

a section of the journal

Frontiers in Forests and Global

Change

Received: 09 February 2021 Accepted: 25 May 2021

Published: 18 June 2021

Citation:

Tonin AM, Lima LS, Bambi P, Figueiredo ML, Rezende RS and

Gonçalves JF (2021) Litterfall

Chemistry Is Modulated by Wet-Dry

Seasonality and Leaf Phenology

of Dominant Species in the Tropics.

Front. For. Glob. Change 4:666116.

doi: 10.3389/ffgc.2021.666116

\section{Litterfall Chemistry Is Modulated by Wet-Dry Seasonality and Leaf Phenology of Dominant Species in the Tropics}

\author{
Alan M. Tonin ${ }^{1 *}$, Laís S. Lima', Paulino Bambi', Monique L. Figueiredo', \\ Renan S. Rezende ${ }^{2}$ and José F. Gonçalves ${ }^{1}$ \\ ' Limnology/Aquaripária Lab, Department of Ecology, Institute of Biological Sciences, University of Brasilia (UnB), Brasilia, \\ Brazil, ${ }^{2}$ Universidade Comunitária da Região de Chapecó, Chapecó, Brazil
}

Litterfall has a large influence on carbon and nutrient cycling of ecosystems, particularly in light-limited forested streams, as most nutrients return in the form of litter. Although recent evidence points to the prevalence of seasonal litterfall in species-rich and evergreen tropical riparian forests, there is a limited understanding of how riparian plant diversity intersects with stream and riparian ecosystem functions. To explore this question, we investigate litterfall chemistry across wet and dry seasons and the congruence between litter traits and plant species composition of litterfall in the wet-dry tropics. Using generalized additive models, we observed consistent seasonal patterns of litterfall chemistry over 2 years, mostly influenced by dominant species in litterfall. While drier seasons showed litter lower in nutrients and structural compounds and higher in polyphenols, litter from wetter seasons were nutrient rich but lower in polyphenols. We also found contrasting seasonal patterns in litterfall chemistry, one showing that litterfall nutrient, structural compounds, and secondary metabolite concentrations declined in drier seasons while the other showed that mass-based litterfall inputs increased markedly in drier seasons. Our findings suggest that litterfall chemistry may be altered by shifts in the identity of dominant plant species and seasonality, possibly leading to changes in carbon and nutrient fluxes in tropical riparian ecosystems.

Keywords: lignin, plant litter, riparian, nitrogen, phosphorus, stream, nutrient cycling, litter decomposition

\section{INTRODUCTION}

Riparian zones are interfaces between forest and freshwater ecosystems tightly linked by the flux of energy and nutrients (Naiman et al., 2005). This connection is especially important to forested headwater streams that are light-limited ecosystems, in which the supply of terrestrial litter is the main energetic source for complex food webs (Wallace et al., 1997; Neres-Lima et al., 2017). Streams 
play a particularly important role in receiving, transporting and processing the litter, contributing to nutrient and carbon fluxes at local, regional and global scales (Raymond et al., 2013; Hotchkiss et al., 2015). Most litter enters streams in the form of senescent leaves-although green leaves may also be found-and through direct fall (hereafter litterfall) or laterally from the forest soil, however, litterfall is often the main route $(>70 \%$ of total litter inputs; Tonin et al., 2017). Consequently, the amount of leaf litter entering streams depend on the timing of leaf senescence of multiple plant species present in the riparian forest (Reich, 1995; Gonçalves and Callisto, 2013).

Plants change the timing of leaf senescence according to environmental cues (e.g., temperature, precipitation, photoperiod), which vary in importance depending on species, biomes and environmental constraints (Tang et al., 2016). For example, in temperate deciduous and coniferous forests-where the majority of studies were done-most of leaf litterfall occurs in autumn as day length shortens and temperature cools (Abelho, 2001). In contrast, tropical forests-which encompass rain, dry and peat swamp forests, and savannas-are often assumed to have lower (or even unpredictable) seasonality of litterfall because of lower temperature and photoperiod seasonality. However, a recent study showed that seasonal litterfall in the tropics is consistently (and negatively) associated with precipitation, even in rainforests, which experiences no dry season (Tonin et al., 2017; but see also Zhang et al., 2014; Nakagawa et al., 2019). In the wet-dry tropics - which include the Cerrado biome in Brazil as well as southern Amazon, central Africa and northern Australia-, most of annual precipitation occurs in certain months of the year (Alvares et al., 2013). Consequently, massive litterfall is produced in the driest periods as a response of plants to reduce water stress (Reich, 1995). Although litterfall has a large influence on carbon and nutrient cycling in forests and streams because most nutrients return in the form of leaf litter (Prescott, 2002), there still are a number of knowledge gaps-especially in the understudied tropical region-including (i) the chemistry of leaf litterfall, and (ii) how it varies year-round and (iii) whether the diversity of leaf phenological patterns in plant communities correlates with the chemistry of litterfall.

Litterfall chemistry is expected to vary year-round because of several mechanisms related to species physiology and environmental controls acting on leaf senescence and/or directly on freshly fallen litter. First, plants are able to resorb nutrients from senescing leaves back into live plant tissues allowing the conservation of nutrients that otherwise would be lost to soils via litterfall (Aerts and Chapin, 1999). Nutrient resorption is then responsible for reducing the concentrations of nitrogen and phosphorus in freshly fallen litter and thus, drive changes in $\mathrm{C}: \mathrm{N}: \mathrm{P}$ balance, which has proven to be a powerful tool for understanding biogeochemical cycling in ecosystems (Elser et al., 2000). Lower soil fertility and drought conditions, both occurring in the Brazilian Cerrado, increase nutrient resorption (Brant and Chen, 2015). Therefore, most leaf litter from riparian forests of Cerrado are nutrient poor with high C:N and C:P mass ratios. Second, polyphenols, that represents the most abundant class of plant secondary compounds, have limited resorption during senescence and its production tends to be stimulated by climatic stress resulting from either drought or increased temperature (Tharayil et al., 2011). Finally, litter chemistry may also be the result of different plant species losing their senescent leaves at different periods of the year. For example, evergreen, semi-deciduous and deciduous species, all occurring in tropical riparian forests, may present distinct patterns of leaf senescence and of annual litter production. While litter of evergreen species may fall year-round or episodically, litter from deciduous species is mostly found in specific seasons (Reich, 1995). Thus, interspecific variation in the timing of litterfall may have important implications for the amounts and composition of carbon and nutrients input to riparian ecosystems, which will ultimately determine the rate of several key ecosystem processes, e.g., litter decomposition, primary production, nutrient cycling.

Our study explored the variation of litter chemical traits across wet and dry seasons, and the congruence between chemical traits and species composition of litter entering streams of the Cerrado biome. We quantified chemical traits related to litter structural compounds, nutrients, secondary metabolites as well as C:N:P stoichiometric mass ratios and the contribution of individual species to litterfall by sampling streams of the Cerrado biome over 2 years. We tested the following hypotheses:

(1) Litter is nutrient ( $\mathrm{N}$ and $\mathrm{P}$ ) poor in drier periods because nutrient resorption occurs before leaf senescence and is a common mechanism of plants to avoid losing important and scarce nutrients. Litter has a greater concentration of secondary metabolites in drier periods because of reduced resorption and drought stress before leaf abscission. We have no a priori expectation about the variability of structural compounds of litter across drier and wetter periods.

(2) Despite the enormous diversity of species that contribute to litterfall in the tropics, litter chemical traits are mostly congruent with the composition of dominant plant species because they comprised the majority of litter biomass.

\section{MATERIALS AND METHODS}

\section{Study Sites}

The study was conducted in three riparian ecosystems encompassing streams and their surrounding vegetation (Capetinga, Cabeça-de-Veado, and Roncador; hereafter CAP, CVE and RON, respectively) in preserved areas of the Cerrado biome (tropical savanna) in central Brazil $\left(15^{\circ} 52^{\prime}-15^{\circ} 59^{\prime} \mathrm{S}\right.$ and $47^{\circ} 50^{\prime}-47^{\circ} 58^{\prime} \mathrm{W}$; Supplementary Table 1). The three riparian ecosystems are part of the Protected Area of Gama Cabeça-de-Veado (23,650 ha) and have similar topography and soil characteristics. They are mostly on plateaus with gentle rolling topography or at the bottom of smooth valleys. Soils within study sites vary from poor to well-drained (hydromorphic soils) and are rich in organic matter and exchangeable aluminum ions, acids and poor in nutrients (Eiten, 1972). Streams are similar in size (mean \pm SE: wetted channel width, $2.5 \pm 0.3 \mathrm{~m}$; water depth: $38 \pm 12 \mathrm{~cm}$ ), with a channel slope of $3.3 \pm 0.9^{\circ}$ and containing a mixture of gravel and silt as streambed substrates. 
Streams flow through dense (84-92\% forest cover) strips of evergreen riparian forests (known as gallery forests) within the savanna (i.e., Cerrado sensu stricto). Riparian forests are evergreen, have trees $20-30 \mathrm{~m}$ tall and a dense understory of low stature (Oliveira-Filho et al., 2002). There is also the presence of semi-deciduous and deciduous species (33 and 13\% of species, respectively, Tonin et al., 2019). Plant species diversity of phanerogams is often high in riparian forests of Cerrado as shown by a previous floristic study in the same area (68 species at CAP, 71 at CVE and 29 at RON in an area of approx. 0.12 ha, Bambi et al., 2017a). Common species in our sites were Protium spruceanum, Pseudomenia laevigata, and Tapirira obtusa at CAP; P. spruceanum, Matayba guianensis, and Cyathea villosa at CVE; and Xilopia emarginata, Richeria grandis, and Clusia criuva at RON. Complementary information on morphological and physical characteristics of these riparian ecosystems can be found in Bambi et al. (2017a) and Tonin et al. (2019).

The studied ecosystems experienced a seasonal tropical climate (Aw, Köppen's climate classification) with a dry season that coincides with the coldest months of the year (JuneAugust) and a wet season (November-March). Additionally, two transitional seasons are evident: the dry-wet (SeptemberOctober) and the wet-dry (April-May). Annual rainfall is around $1,477 \mathrm{~mm}$ and mean air temperature is $21^{\circ} \mathrm{C}$ (National Institute of Meteorology (1981-2010); Figure 1). During the 2 years of this study, annual rainfall was $1,418 \mathrm{~mm}$ and mean air temperature was $21.1^{\circ} \mathrm{C}$.

\section{Field and Laboratory Work}

We analyzed the chemical composition (hereafter chemical traits) and plant species composition of leaf litter entering the three streams. Our study focused on leaf litter because it represented the majority of inputs (Tonin et al., 2017) and it is a biologically active component in forest streams that is replaced throughout the year (Webster et al., 1999). Litterfall was collected in each stream using suspended traps distributed at 5 equally distanced sampling sites along a 50-100 m reach. Sampling sites were selected to be representative of reaches, mostly avoiding large gaps in forest canopies or large trees. Litter traps were plastic buckets with small holes in the bottom for drainage $(26 \mathrm{~cm}$ in diameter) that were placed $2 \mathrm{~m}$ above the streambed. Traps were installed using ropes tied to trees along the streambank and in a perpendicular direction to the stream channel. At each site, a total of 18 litter traps were installed on three ropes, each with six traps, which is equivalent to a sampling effort of approximately $1 \mathrm{~m}^{2}$. Ropes were located several centimeters from one another and along each rope traps were equally distributed to cover the stream channel and therefore maximize the capture of litterfall.

Leaf litter (hereafter litter) was collected once a month for 2 years, comprising a total of 24 sampling events (from September 2010 to September 2012) (see Bambi et al., 2017b; Tonin et al., 2019). All litter from a site were pooled together (18 traps) per sampling event. In the laboratory, samples were first air-dried, identified to the species level, oven dried $\left(60^{\circ} \mathrm{C}\right.$ for $\left.72 \mathrm{~h}\right)$ and weighed separately per species. Species identification was done only for a subset of samples (i.e., samples of the first year of study collected between September 2010 and August 2011) due to logistical reasons, using the databases of the Tropics projects ${ }^{1}$, the Flora do Brazil species list ${ }^{2}$, the Field Museum ${ }^{3}$ and the Link species network ${ }^{4}$, based on the APG III classification system.

Secondly, all species from a sample were mixed, oven-dried $\left(60^{\circ} \mathrm{C}\right.$ for $\left.72 \mathrm{~h}\right)$, ground in a ball mill to powder and chemically analyzed for the concentration of structural compounds [carbon

\footnotetext{
${ }^{1}$ http://www.tropicos.org

${ }^{2}$ http://floradobrasil.jbrj.gov.br/reflora

${ }^{3}$ http://www.fieldmuseum.org

${ }^{4}$ http://www.splink.org.br
}

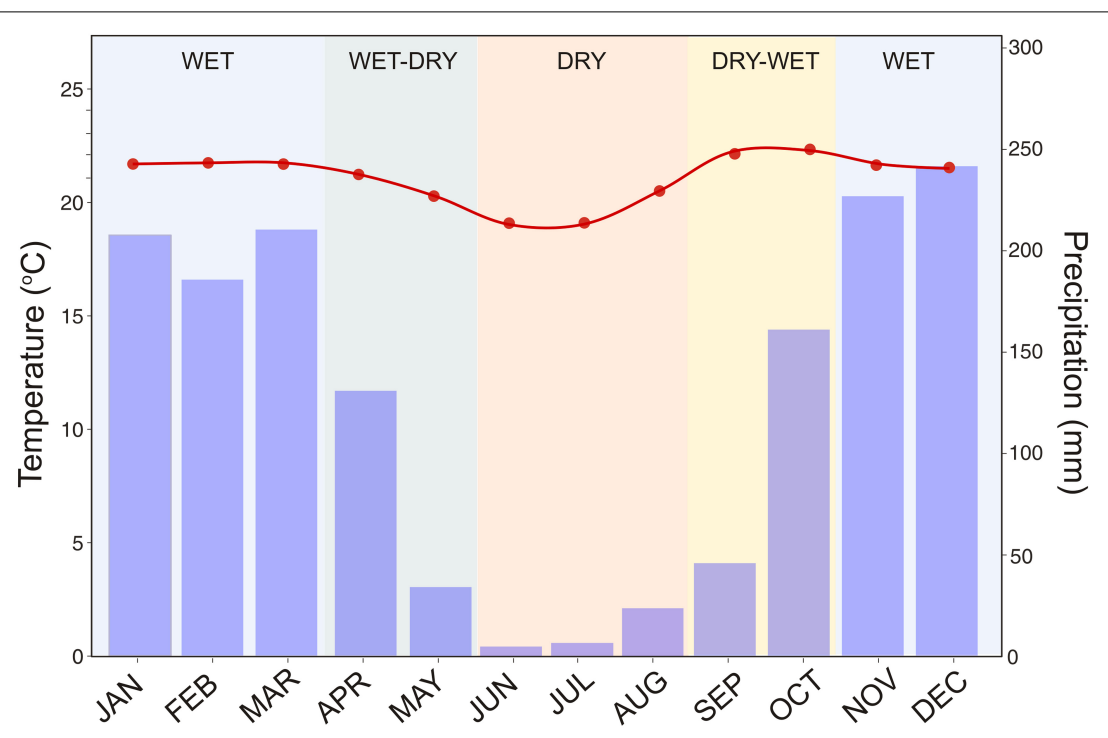

FIGURE 1 | Climatogram of the Brazilian Cerrado using records of precipitation (bars) and temperature (red points and lines) from 1981 to 2010. Data from National Institute of Meteorology (1981-2010) (INMET) for Brasilia station. 
(C), fibers, lignin and cellulose], nutrients [nitrogen $(\mathrm{N})$ and phosphorus $(\mathrm{P})$ ] and secondary metabolites (polyphenols). The concentration of $\mathrm{C}$ and $\mathrm{N}$ was determined in an elemental analyzer (Leco Corporation-TruSpec Micro CHN628) by total combustion of litter sample at $950^{\circ} \mathrm{C}$ and detection of $\mathrm{C}$ and $\mathrm{N}$ in the form of $\mathrm{CO}_{2}$ and $\mathrm{N}_{2}$, respectively. Fibers, lignin (as proximate lignin) and cellulose were obtained gravimetrically using the acid-detergent fiber procedures proposed by Goering and Van Soest (1970) with slight modifications (Gessner, 2005). Briefly, this method consists in the determination of residual weight of samples after successive extraction of tissue constituents. Phosphorus was quantified as phosphate $\left(\mathrm{PO}_{4}-\mathrm{P}\right)$ spectrophotometrically (measuring absorbance at $882 \mathrm{~nm}$ ) using the ascorbic acid method after combustion $\left(550^{\circ} \mathrm{C}\right.$ for $4 \mathrm{~h}$ ) and digestion (with hydrochloric acid) of litter samples (Flindt and Lillebø, 2005). Polyphenols were determined by the FolinCiocalteu method (Folin and Ciocalteu, 1927) which consists in extracting phenol hydroxyl groups from litter samples with $70 \%$ acetone for $1 \mathrm{~h}$ at $4^{\circ} \mathrm{C}$, reading absorbance at $760 \mathrm{~nm}$ in spectrophotometer and determine phenolic concentration in terms of tannic acid equivalents (Bärlocher and Graça, 2005).

\section{Calculation of Litter Traits}

Litter traits were expressed as concentrations (in percentage) of each chemical compound or mass ratios of C:N, C:P, and N:P per month at each sampling site. The amount of litter constituents in terms of masses was estimated by multiplying the proportion of each constituent by litterfall mass. Litterfall was calculated as litter dry mass (in grams) divided by the area of traps in a site (i.e., $0.9558 \mathrm{~m}^{2}$ ) and the elapsed time (in days), multiplied by 30 days to estimate monthly litterfall. The contribution of each species to litterfall was calculated similarly, but to the scale of a riparian ecosystem, as litter dry mass of a species (in grams) divided by the area of traps in an ecosystem (i.e., $4.779 \mathrm{~m}^{2}$ ) and the elapsed time (in days) multiplied by 30 days.

\section{Data Analyses}

All analyses were conducted in R v. 4.0.1 (R Core Team, 2020) using the packages mgcv (Wood, 2011), nlme (Pinheiro et al., 2020), tidyverse (Wickham et al., 2019), and vegan (Oksanen et al., 2020) and figures were prepared using ggplot2 (Wickham, 2016). Initial data exploration revealed potential non-linear patterns of litter chemical traits over time and remarkably similarities of these data across riparian ecosystems,- - supporting its inclusion as a random term in the generalized additive mixed models (GAMMs). Further data exploration also indicated (i) different variance over time, which was taken into account while structuring and validating the models and (ii) high variability and the presence of true extreme observations in N:P mass ratio data, which required a log-transformation prior to analysis.

We thus explored temporal dynamics of litter chemical traits in terms of concentrations and mass with GAMMs with time (number of each sampling event) as a continuous predictor and riparian ecosystems as a random term for each chemical compound separately. Models were fitted with time as a smooth term, with a normal distribution of response data, the identity-link function and restricted maximum likelihood method. This type of model (also known as smoothing models) was used because they allow for non-linear relationships of the response variable in relation to the predictor (Zuur et al., 2009). The optimal amount of smoothing was estimated with cross-validation and expressed as effective degrees of freedom (edf). The higher the edf, the more non-linear is the smoother. Variance was allowed to differ among sampling events using a constant variance function structure (VarIdent) to meet the homogeneity assumption (Zuur and Ieno, 2015). The need for this term was identified in initial data exploration and confirmed by comparison of the Akaike Information Criterion (AIC) of models with and without this component. Neither spatial autocorrelation within and among streams nor temporal autocorrelation between subsequent sampling events were detected. We checked for spatial and temporal autocorrelation using variograms and the autocorrelation function of normalized model residuals, respectively. Graphical diagnostics were used as validation tools for the models: QQ-plots and histograms of residuals to assess normality and residuals versus fitted values for homogeneity.

We investigated the congruence between plant species composition of litterfall and litter chemical traits over time with redundancy analysis (RDA). Species data was structured to represent one observation of each riparian ecosystem at each sampling event per species. Therefore, litter chemical traits were averaged across sites per riparian ecosystem per sampling event. We first fitted an RDA model using all plant species data as a response matrix (Hellinger-transformed) and litter traits as a matrix of predictors ( $\mathrm{z}$-score transformed). We then fitted a second RDA model using only the dominant species to test whether the litter trait variability is more congruent with the phenology of the dominant species. Four non-colinear litter traits (i.e., carbon, C:N mass ratio, cellulose and lignin) were retained and used in the matrix of predictors after evaluation of pairwise correlations between traits (Supplementary Table 2) and adequacy of variance inflation factors of RDA. Statistical significance of the global RDA models and of its axes were obtained by permutation tests using 999 iterations.

\section{RESULTS}

\section{Variation of Litter Chemistry Across Seasons}

All litter traits related to structure, nutrients (except N:P mass ratio) and secondary metabolism showed a consistent non-linear variation across dry and wet seasons (Table 1 and Figure 2). The concentration of structural compounds (carbon, fibers, lignin and cellulose) and nutrients ( $\mathrm{N}$ and $\mathrm{P}$ ) were highest in wet and wet-dry transition seasons and decreased toward the dry season or until the beginning of the dry-wet transition. In contrast, secondary metabolites (polyphenols), and C:N and C:P mass ratios revealed the opposite pattern with highest values in dry and dry-wet seasons and a decrease toward the wet seasons. Our models also showed higher seasonal variance of nutrients than of carbon. 
TABLE 1 | Results of generalized additive mixed models (GAMMs) exploring non-linear temporal patterns of litter traits in terms of concentrations (\%) or mass $\left(\mathrm{g} \mathrm{m}^{-2}\right.$ month $^{-1}$ ) of each compound or C:N, C:P, and N:P ratios over 2 years.

\begin{tabular}{lrrrrr}
\hline & Intercept & edf & F-value & $\boldsymbol{P}$-value & $\boldsymbol{R}^{\mathbf{2}}$ \\
\hline \%Carbon & 49.75 & 7.65 & 12.99 & $<0.001$ & 0.14 \\
\%Nitrogen & 1.19 & 8.29 & 30.64 & $<0.001$ & 0.38 \\
\%Phosphorus & 0.01 & 7.34 & 15.35 & $<0.001$ & 0.16 \\
\%Polyphenols & 3.62 & 8.83 & 60.55 & $<0.001$ & 0.59 \\
\%Lignin & 22.64 & 7.11 & 11.22 & $<0.001$ & 0.18 \\
\%Cellulose & 42.26 & 8.04 & 39.89 & $<0.001$ & 0.45 \\
\%Fibers & 67.81 & 8.43 & 25.46 & $<0.001$ & 0.38 \\
C:N mass ratio & 42.43 & 8.42 & 37.12 & $<0.001$ & 0.40 \\
C:P mass ratio & 4203.5 & 8.01 & 14.66 & $<0.001$ & 0.21 \\
N:P mass ratio* & 4.58 & 3.42 & 1.28 & 0.177 & 0.01 \\
Carbon mass & 11.16 & 8.83 & 47.93 & $<0.001$ & 0.42 \\
Nitrogen mass & 0.26 & 8.82 & 41.82 & $<0.001$ & 0.37 \\
Phosphorus mass & 0.003 & 8.63 & 25.09 & $<0.001$ & 0.33 \\
Polyphenols mass & 0.80 & 8.85 & 32.87 & $<0.001$ & 0.34 \\
Lignin mass & 5.34 & 8.78 & 37.52 & $<0.001$ & 0.38 \\
Cellulose mass & 8.66 & 8.78 & 32.59 & $<0.001$ & 0.31 \\
Fibers mass & 14.09 & 8.78 & 35.90 & $<0.001$ & 0.33 \\
\hline
\end{tabular}

The amount of smoothing of models is presented as the effective degrees of freedom (edf) in relation to time (i.e., sampling events). We show estimated intercepts for each variable, values of $F$ and $P$ for the smoother and adjusted $R^{2}$ for the GAMMs.

* Log-transformed variable.

When the amount of litter constituents in terms of mass that enter streams is taken into account a different pattern was found. The mass of all litter constituents (structural, nutrients and secondary metabolites) was two to threefold higher in drywet (when litterfall is greatest) than in wet or wet-dry seasons (Table 1 and Figure 3).

\section{Congruence Between Litter Traits and Species Composition of Litterfall}

Litterfall entering the three streams and across the four seasons was comprised of 142 plant species (85 species at CVE, 84 at CAP and 39 at RON stream). However, $64-74 \%$ of species (or 25-63 species) contributed less than 1\% of annual litterfall biomass. As a result, 9-12 species dominated litter phenological patterns and were responsible for more than $70 \%$ of annual litter biomass (Figure 4 and Supplementary Figure 1). Although some of the dominant species contributed at certain periods of the year, others were present year-round (e.g., Vochysia pyramidalis, Protium spruceanum, Calophyllum brasiliense, Xylopia emarginata) (Figure 4). Dominant species or genus that were found in the three riparian ecosystems showed similar litterfall patterns as supported by Calophyllum brasiliense and Myrcia (Figure 4).

The redundancy analysis (RDA) using data from all species showed that $46 \%$ of total variation (i.e., constrained variance) of species composition data was related to litter trait variation across streams and seasons (Table 2). The RDA ordination evidenced that species with lower $\mathrm{C}: \mathrm{N}$ mass ratios and lower cellulose were more frequent at CVE (e.g., Ormosia arborea and
Myrcia tenuifolia), species with higher $\mathrm{C}$ but lower lignin at CAP (e.g., Vochysia pyramidalis) and species with higher C:N mass ratios, higher cellulose and higher lignin at RON (e.g., Xylopia emarginata and Clusia criuva) (Figure 5A). Patterns across seasons were apparent within streams. For example, the dry season was mostly related to higher C:N ratios and lower lignin, while wet season showed the opposite pattern with lower $\mathrm{C}: \mathrm{N}$ ratios and higher lignin content. Also, the dry-wet season was more similar (i.e., closest in the RDA ordination) to the wet season and the wet-dry to the dry season (Figure 5A).

A second RDA using species composition of only dominant species indicated that dominant species were driving the variability in litter traits across streams and seasons. This second RDA explained a higher percentage of total variation (46\% in the first vs. $49 \%$ in this second RDA) while maintaining the same patterns of the first RDA ordination, supporting the predominant role of dominant species in litterfall chemistry (Figure 5B and Table 2).

\section{DISCUSSION}

Our study showed clear seasonal patterns of litterfall chemistry, which were largely driven by dominant species in riparian forests of Brazilian Cerrado. Importantly, we found contrasting seasonal patterns in the concentrations and mass of litter traits. Despite the importance of understanding leaf phenological patterns in forests and riparian ecosystems to carbon and nutrient cycling, most available literature is still restricted to temperate and boreal regions (e.g., Niinemets and Tamm, 2005; Montgomery et al., 2020) or focused on specific sets of plant species (e.g., habits, functional type; Panchen et al., 2015). This is surprising considering that the tropics cover $40 \%$ of the Earth's land surface, harbor a high diversity of plants, and are responsible for processing a considerable portion of organic matter globally (Wright, 1996; Tiegs et al., 2019). Within this context, our findings contribute to the understanding of basic aspects of carbon and nutrient dynamics and help to disentangle how riparian diversity influence stream and riparian ecosystem functions.

The seasonal patterns of litterfall chemistry observed here could due to $(i)$ species seasonal variation in litter chemistry (e.g., species with different litter chemistry in drier and wetter seasons because of different rates of nutrient resorption or leaf development), (ii) different species composition of litterfall (e.g., higher litterfall mass of a nutrient or lignin-rich species), (iii) intra-species litter chemistry variability (e.g., individuals of a species that produce litter with different chemistry) or (iv) the occurrence of all the above-mentioned mechanisms. Our finding that the species composition of litterfall is strongly coordinated with seasonal variation in litterfall chemistry indicates that interspecific variation in leaf senescence plays a determinant role in riparian ecosystem functions. Although intra-species variability in litter chemistry is expected (and was not tested in this study due to the lack of data), it has been shown to be lower than inter-species variability (Anderegg et al., 2018). 

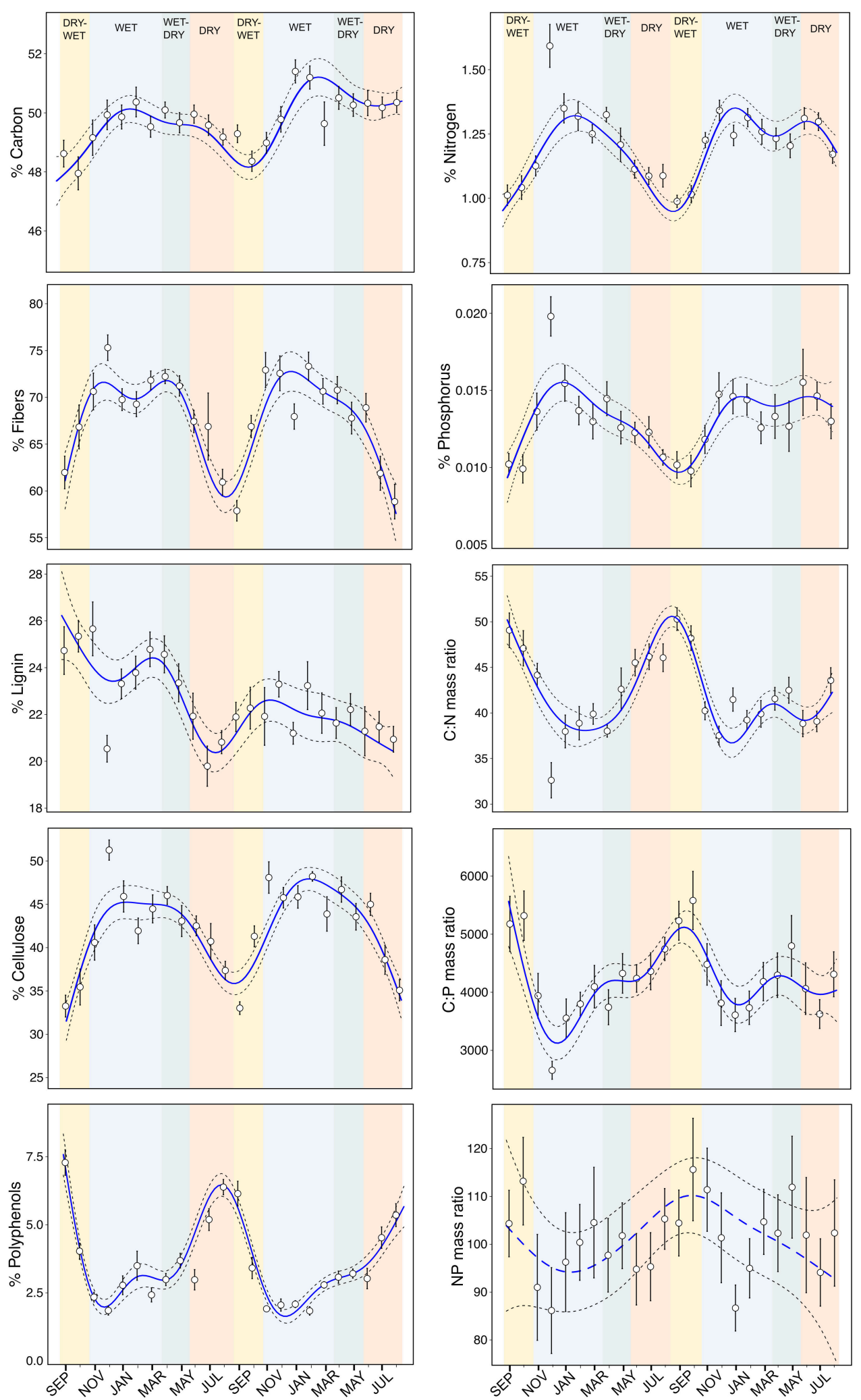

FIGURE 2 | Temporal patterns of litter traits as concentrations of each compound and, ratios of C:N, C:P, and N:P across the four seasons (dry-wet, wet, wet-dry, and dry seasons) over 2 years. Blue lines represent the non-linear temporal trend from generalized additive mixed models and dashed lines the 95\% confidence intervals of the models. Circles are means and vertical lines denote upper and lower limits of standard errors from data of multiple sampling sites within streams. 

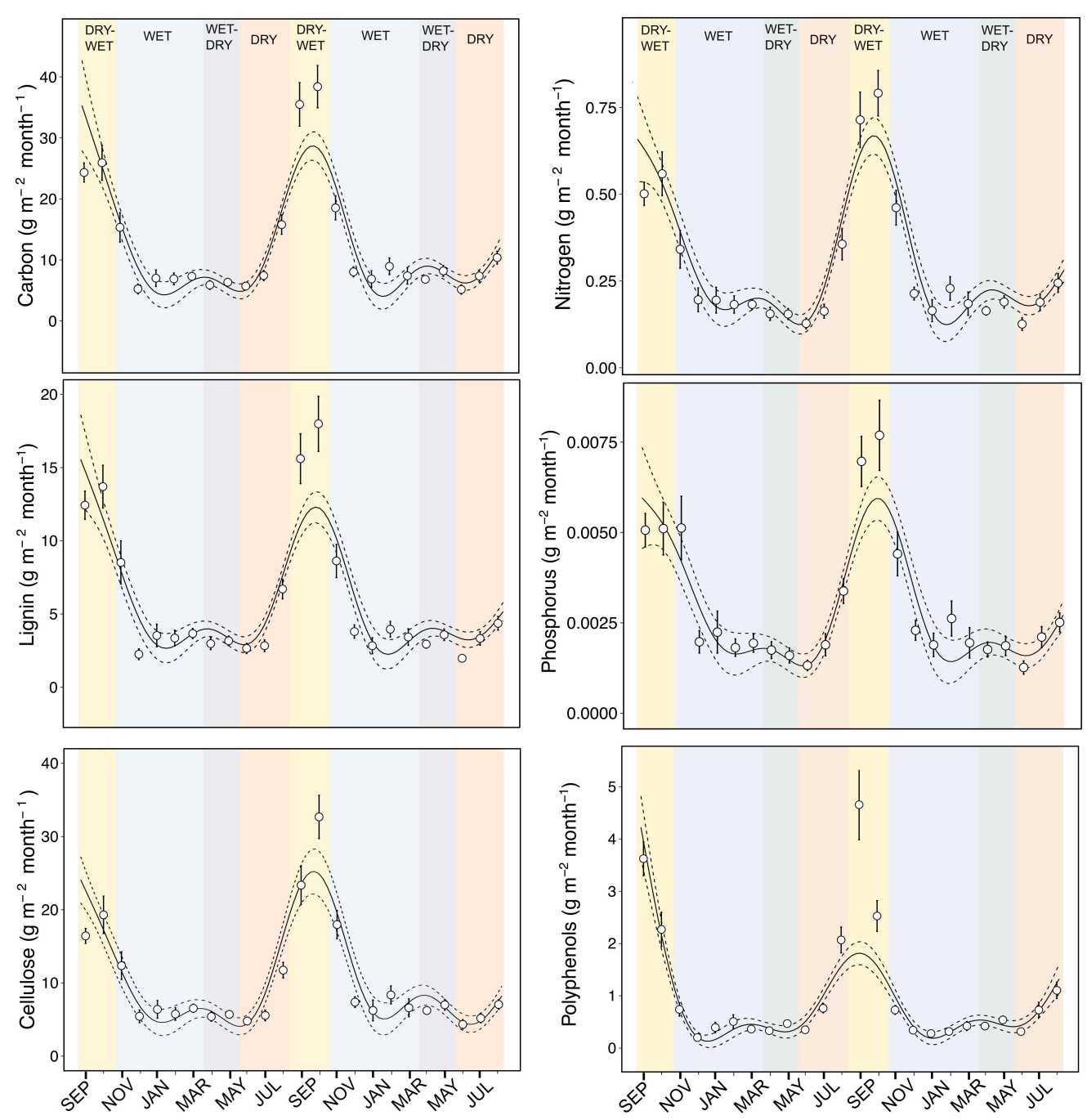

FIGURE 3 | Temporal patterns of litter traits as the mass of each compound ( $\mathrm{g} \mathrm{m}^{-2} \mathrm{month}^{-1}$ ) across the four seasons (dry-wet, wet, wet-dry, and dry seasons) over 2 years. Solid lines represent the non-linear temporal trend from generalized additive mixed models and dashed lines the $95 \%$ confidence intervals of the models. Circles are means and vertical lines denote upper and lower limits of standard errors from data of multiple sampling sites within streams.

Taken together, these results suggest that litterfall chemistry (on an annual or seasonal basis) is primary driven by the chemical composition of dominant species occurring in riparian forests.

Seasonally distinct litter chemistry of a species may reflect the influence of intrinsic (e.g., plant development) and extrinsic environmental controls (e.g., climate). In our study, nutrient resorption may have reduced nitrogen and phosphorus of litter from wetter to drier periods, when their concentrations were lowest and carbon to nutrient ratios were highest, as shown elsewhere (Anaya et al., 2007 in tropical dry forests; Heartsill-Scalley et al., 2012 in tropical rainforests). Nitrogen and phosphorus resorption plays a key role in nutrient conservation of plants (Brant and Chen, 2015) and its importance was previously reported for plant species of Cerrado biome (Kozovits et al., 2007). It is also noteworthy that the seasonal patterns of carbon is likely to be associated with those of N and P, as carbon assimilation by plants through photosynthesis is maximized only if sufficient nutrients are allocated to leaves under optimum irradiance (Hikosaka, 2005). A plausible explanation for the higher seasonal variance of nutrients besides carbon is that the former are limiting elements in most plants-and are reabsorbed before leaf senescence and recycled multiple time (Han et al., 2013; Brant and Chen, 2015), - while the turnover of the carbon is faster given its assimilation from the atmosphere (Chambers et al., 2004).

In contrast, seasonal changes in structural compounds may be associated with the growing season and leaf development of most (or dominant) plant species that coincide with first rains (i.e., the transition between dry and wet season) (Reich and Borchert, 1984; Reich, 1995). During leaf development, there is a continuous production of cell walls consisting of strong fiberrich composite materials such as lignin and cellulose, explaining their increase from drier to wetter seasons, which promote mechanical resistance to protect leaves from herbivores, wind 

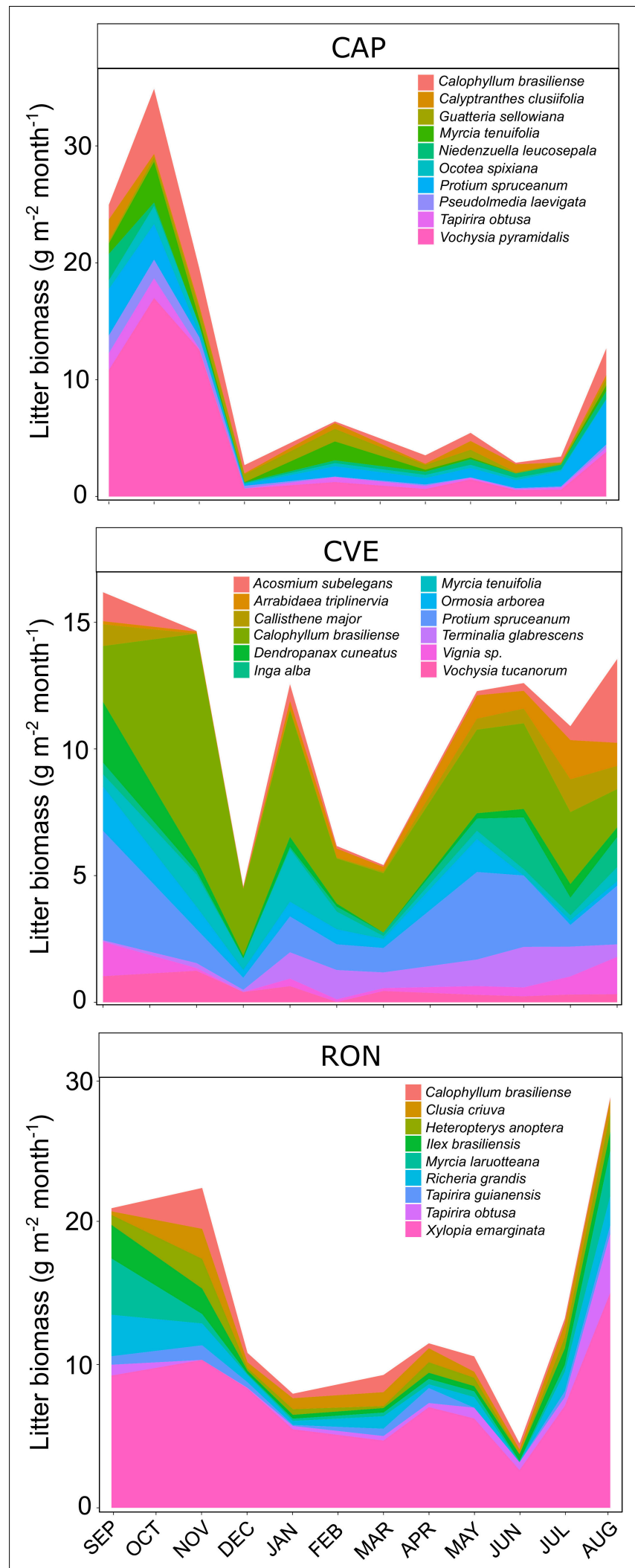

FIGURE 4 | Litter biomass of the dominant plant species (in $\mathrm{g} \mathrm{m}^{-2} \mathrm{month}^{-1}$ ) entering each stream (CAP, CVE, and RON) over 1 year (September 2010 to August 2011).
TABLE 2 | Results of redundancy analysis (RDA) exploring the congruence between plant species composition of litterfall and litter chemical traits over time.

\begin{tabular}{lcccc}
\hline & Variance & \% Variance & $\boldsymbol{F}$-value & $\boldsymbol{P}$-value \\
\hline (1) RDA - all plant species & 0.271 & 46 & 5.38 & $<0.001$ \\
RDA Axis 1 & 0.160 & 27 & 12.67 & $<0.001$ \\
RDA Axis 2 & 0.087 & 15 & 6.92 & $<0.001$ \\
RDA Axis 3 & 0.016 & 3 & 1.30 & 0.498 \\
RDA Axis 4 & 0.008 & 1 & 0.61 & 0.733 \\
Residual (unconstrained) & 0.315 & 54 & & \\
(2) RDA-dominant species & 0.264 & 49 & 6.09 & $<0.001$ \\
RDA Axis 1 & 0.164 & 30 & 15.18 & $<0.001$ \\
RDA Axis 2 & 0.081 & 15 & 7.50 & 0.003 \\
RDA Axis 3 & 0.014 & 2 & 1.25 & 0.505 \\
RDA Axis 4 & 0.005 & 1 & 0.44 & 0.821 \\
Residual (unconstrained) & 0.271 & 51 & & \\
\hline
\end{tabular}

The first RDA used all species data; the second RDA used only dominant species. Four non-colinear traits summarizing chemical variation of litter were used in both RDA analyses (i.e., carbon, C:N, cellulose and lignin). We show the variance and percentage of variance for RDAs, axes and residuals, and values of $F$ and $P$ for RDAs and axes.

and other risks of injury (Boyero et al., 2017). Increases in polyphenols content on litter from wetter to drier seasons might be due a stimulation of polyphenols production by climatic stressors such as drought or increased temperature (Tharayil et al., 2011). An alternative explanation underlying decreases in polyphenols would be leaching of senescing leaves, before or even after falling in traps, during periods of heavy rainfall, as demonstrated previously (Serrano, 1992). However, it is unlikely that leaching was responsible for such striking reductions of polyphenols given that thick cuticles of most leaves may attenuate leaching losses.

We show that, despite litter having lower concentrations of nitrogen and structural compounds in drier seasons, the amount of all litter constituents added to soils and streams was remarkably (2-3 times) higher in drier seasons as a consequence of higher litterfall mass. This suggests the existence of two contrasting patterns providing complementary information to the understanding of ecosystem functions. First, exploring the seasonality of the concentrations of each litter constituent allows for the prediction of rates for key ecosystem processes in both forests and streams, such as decomposition and nutrient cycling that depend on physical and biological agents (Marks, 2019). For example, lower in-stream litter decomposition reported in the dry season (e.g., Tonin et al., 2019) may be related to the higher C:N or C:P ratios observed in this study, and thus a lower availability of nutrients to decomposers and detritivores. Second, quantifying the mass of litter constituents provides a more holistic view of the ecosystem in terms of fluxes of elements and organic molecules from litterfall to the forest soils and stream. Thus, periods of large accumulation of elements and organic compounds such as nutrients or fiber-rich materials may drive the chemistry of soils and water (especially in low-flow conditions) stimulating or retarding the biological activity (Lutz et al., 2012). These contrasting patterns also indicate that there is a trade-off between lower amounts of higher-quality litter and higher amounts of lower-quality litter over the year. Such a trade-off may 


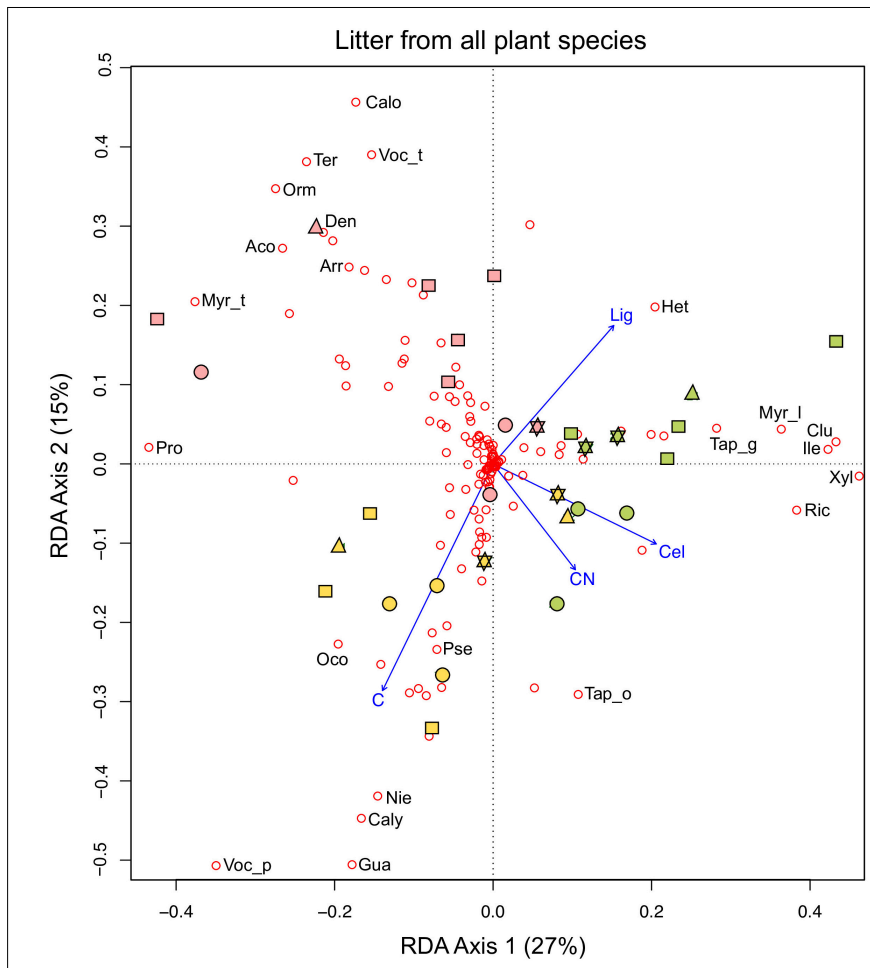

Season $\triangle$ Dry-Wet $\square$ Wet Wet-Dry ODry

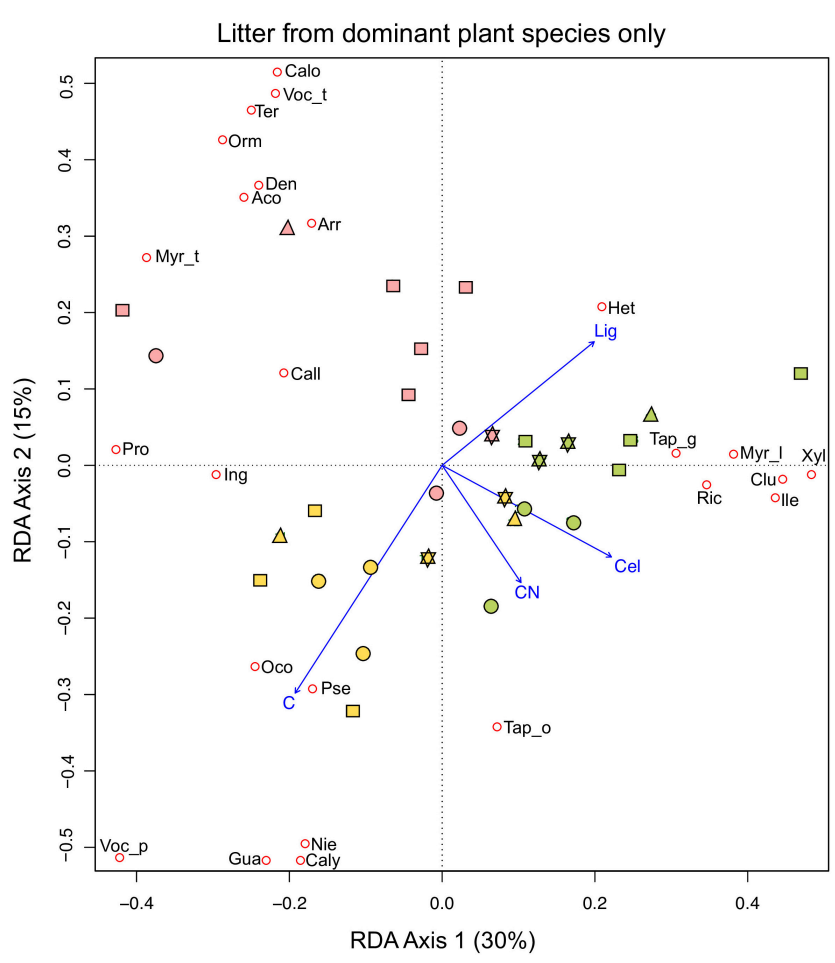

Riparian ecosystem $\bigcirc$ CAP $\bigcirc$ CVE $\bigcirc$ RON

FIGURE 5 | Biplot ordinations of redundancy analyses (RDA) exploring the congruence between plant species composition of litterfall and litter chemical traits. Four non-colinear traits summarizing the chemical variation of litter were used in both RDA analyses (i.e., carbon, C:N, cellulose and lignin). Species data are shown with non-filled red circles. Species acronyms are shown only for the dominant species. Acronyms are the three initial letters of each species (or four letters if a genus represent more than one species) described in Figure 4.

enable litter-consuming detritivores and microbial decomposers to meet their nutritional demands, suggesting that abundant low-quality litter may provide a long-term resource once the more nutritious and scarce litter is gone. However, experimental evidence suggests that compensatory feeding on poorer resources may be necessary to alleviate nutritional imbalances of organisms (Ott et al., 2012; Flores et al., 2014).

We provide novel evidence of seasonal patterns of leaf litterfall chemistry, mostly driven by the composition of dominant plant species in litterfall, in wet-dry tropical riparian ecosystems. We also show that seasonal patterns in litterfall chemistry revealed two contrasting perspectives, if presented in terms of concentrations or mass of compounds. Thus, we can no longer assume that tropical riparian forests and streams have less clear seasonal patterns than temperate or boreal ecosystems. While our study emphasizes the contributions of dominant species in determining the concentrations and amounts of $\mathrm{C}$, $\mathrm{N}$, and $\mathrm{P}$ in litter, it is possible that rare species contribute disproportionately to ecosystem functions or in the provisioning of essential elements (such as micronutrients) not considered in this study (cf. Mouillot et al., 2013). The applicability of our findings to other tropical riparian ecosystems should interpreted with caution given the limitations of the spatial scale of this study. Our results provide a basis for understanding how plant litter resources influence the biogeochemistry of riparian ecosystems and for predicting the consequences of potential future shifts of rainfall seasonality for ecosystem processes.

\section{DATA AVAILABILITY STATEMENT}

The datasets generated for this study are available at figshare (https://doi.org/10.6084/m9.figshare.14538162.v1).

\section{AUTHOR CONTRIBUTIONS}

AT, JG, and RR conceived the study. PB and AT collected field data. LL and MF performed the chemical analyses. AT managed and analyzed the data. AT wrote the manuscript with feedback from JG and other authors. All authors contributed to the article and approved the submitted version.

\section{FUNDING}

This study was supported by the projects PROCAD-NF/CAPES-173/2010 and 296/2010, CAPES/PNADB1098/2010, MCTI/CNPq/Universal-477545/2010-6 and 
471767/2013-1, CNPq/PQ-302957/2014-6, MCTI/PELD/CNPq558233/2009-0, MCT/CNPq/FNDCT/FAPs/MEC/CAPES/ PRO-CENTRO-OESTE-031/2010, EMBRAPA 01/2011, FAP-DF-193.000.870/2015, FAPEMIG-APQ-00274-12 and University of Brasília DPP 121366/2011.

\section{REFERENCES}

Abelho, M. (2001). From litterfall to breakdown in streams: a review. Sci. World J. 1, 656-680. doi: 10.1100/tsw.2001.103

Aerts, R., and Chapin, F. S. (1999). "The mineral nutrition of wild plants revisited: a re-evaluation of processes and patterns," in Advances in Ecological Research, Vol. 30, eds A. H. Fitter and D. G. Raffaelli (Cambridge, MA: Academic Press), 1-67. doi: 10.1016/s0065-2504(08)60016-1

Alvares, C. A., Stape, J. L., Sentelhas, P. C., de Moraes, G., Leonardo, J., and Sparovek, G. (2013). Köppen's climate classification map for Brazil. Meteorol. Z. 22, 711-728. doi: 10.1127/0941-2948/2013/0507

Anaya, C. A., García-Oliva, F., and Jaramillo, V. J. (2007). Rainfall and labile carbon availability control litter nitrogen dynamics in a tropical dry forest. Oecologia 150, 602-610. doi: 10.1007/s00442-006-0564-3

Anderegg, L. D. L., Berner, L. T., Badgley, G., Sethi, M. L., Law, B. E., and HilleRisLambers, J. (2018). Within-species patterns challenge our understanding of the leaf economics spectrum. Ecol. Lett. 21, 734-744. doi: 10.1111/ele.12945

Bambi, P., de Souza Rezende, R., Cruz, T. M., de Araújo Batista, J. E., Graciano, F. G., Santos, L. V., et al. (2017a). Diversidade da flora fanerogâmica de três matas de galeria no bioma Cerrado. Heringeriana 10, 147-167. doi: 10.17648/ heringeriana.v10i2.224

Bambi, P., de Souza Rezende, R., Feio, M. J., Leite, G. F. M., Alvin, E., Quintão, J. M. B., et al. (2017b). Temporal and spatial patterns in inputs and stock of organic matter in savannah streams of central Brazil. Ecosystems 20, 757-768. doi: $10.1007 / \mathrm{s} 10021-016-0058-\mathrm{Z}$

Bärlocher, F., and Graça, M. S. (2005). “Total phenolics," in Methods to Study Litter Decomposition, eds M. A. S. Graça, F. Bärlocher, and M. O. Gessner (Dordrecht: Springer), 97-100. doi: 10.1007/1-4020-3466-0_14

Boyero, L., Graça, M. A. S., Tonin, A. M., Pérez, J., Swafford, A., Ferreira, V., et al. (2017). Riparian plant litter quality increases with latitude. Sci. Rep. 7:10562. doi: 10.1038/s41598-017-10640-3

Brant, A. N., and Chen, H. Y. H. (2015). Patterns and mechanisms of nutrient resorption in plants. Crit. Rev. Plant Sci. 34, 471-486. doi: 10.1080/07352689. 2015.1078611

Chambers, J. Q., Tribuzy, E. S., Toledo, L. C., Crispim, B. F., Higuchi, N., dos Santos, J., et al. (2004). Respiration from a tropical forest ecosystem: partitioning of sources and low carbon use efficiency. Ecol. Appl. 14, 72-88. doi: 10.1890/01-6012

Eiten, G. (1972). The cerrado vegetation of Brazil. Bot. Rev. 38, 201-341. doi: $10.1007 / \mathrm{BF} 02859158$

Elser, J. J., Sterner, R. W., Gorokhova, E., Fagan, W. F., Markow, T. A., Cotner, J. B., et al. (2000). Biological stoichiometry from genes to ecosystems. Ecol. Lett. 3, 540-550. doi: 10.1111/j.1461-0248.2000.00185.x

Flindt, M. R., and Lillebø, A. I. (2005). "Determination of total nitrogen and phosphorus in leaf litter," in Methods to Study Litter Decomposition, eds M. A. S. Graça, F. Bärlocher, and M. O. Gessner (Dordrecht: Springer), 53-59. doi: 10.1007/1-4020-3466-0_8

Flores, L., Larrañaga, A., and Elosegi, A. (2014). Compensatory feeding of a stream detritivore alleviates the effects of poor food quality when enough food is supplied. Freshw. Sci. 33, 134-141. doi: 10.1086/674578

Folin, O., and Ciocalteu, V. (1927). On tyrosine and tryptophane determinations in proteins. J. Biol. Chem. 73, 627-650. doi: 10.1016/s0021-9258(18)84277-6

Gessner, M. O. (2005). "Proximate lignin and cellulose," in Methods to Study Litter Decomposition, eds F. Bärlocher, M. A. S. Graça, and M. O. Gessner (Cham: Springer), 115-120. doi: 10.1007/1-4020-3466-0_17

Goering, H. K., and Van Soest, P. J. (1970). Forage Fiber Analyses (apparatus, Reagents, Procedures, and Some Applications). Washington, DC: U.S. Agricultural Research Service.

\section{SUPPLEMENTARY MATERIAL}

The Supplementary Material for this article can be found online at: https://www.frontiersin.org/articles/10.3389/ffgc.2021. 666116/full\#supplementary-material

Gonçalves, J. J. F., and Callisto, M. (2013). Organic-matter dynamics in the riparian zone of a tropical headwater stream in Southern Brasil. Aquat. Bot. 109, 8-13. doi: 10.1016/j.aquabot.2013.03.005

Han, W., Tang, L., Chen, Y., and Fang, J. (2013). Relationship between the relative limitation and resorption efficiency of nitrogen vs phosphorus in woody plants. PLoS One 8:e83366. doi: 10.1371/journal.pone.0083366

Heartsill-Scalley, T., Scatena, F. N., Moya, S., and Lugo, A. E. (2012). Long-term dynamics of organic matter and elements exported as coarse particulates from two Caribbean montane watersheds. J. Trop. Ecol 28, 127-139. doi: 10.1017/ S0266467411000733

Hikosaka, K. (2005). Leaf canopy as a dynamic system: ecophysiology and optimality in leaf turnover. Ann. Bot. 95, 521-533. doi: 10.1093/aob/mce3i050

Hotchkiss, E. R., Hall, R. O. Jr., Sponseller, R. A., Butman, D., Klaminder, J., Laudon, H., et al. (2015). Sources of and processes controlling CO2 emissions change with the size of streams and rivers. Nat. Geosci. 8, 696-699. doi: 10.1038/ ngeo 2507

Kozovits, A. R., Bustamante, M. M. C., Garofalo, C. R., Bucci, S., Franco, A. C., Goldstein, G., et al. (2007). Nutrient resorption and patterns of litter production and decomposition in a Neotropical Savanna. Funct. Ecol. 21, 1034-1043. doi: 10.1111/j.1365-2435.2007.01325.x

Lutz, B. D., Mulholland, P. J., and Bernhardt, E. S. (2012). Long-term data reveal patterns and controls on stream water chemistry in a forested stream: walker branch tennessee. Ecol. Monogr. 82, 367-387. doi: 10.1890/11-1129.1

Marks, J. C. (2019). Revisiting the fates of dead leaves that fall into streams. Annu. Rev. Ecol. Evol. Syst. 50, 547-568. doi: 10.1146/annurev-ecolsys-110218024755

Montgomery, R. A., Rice, K. E., Stefanski, A., Rich, R. L., and Reich, P. B. (2020). Phenological responses of temperate and boreal trees to warming depend on ambient spring temperatures, leaf habit, and geographic range. Proc. Natl. Acad. Sci.U.S.A. 117, 10397-10405. doi: 10.1073/pnas.1917508117

Mouillot, D., Bellwood, D. R., Baraloto, C., Chave, J., Galzin, R., Harmelin-Vivien, M., et al. (2013). Rare species support vulnerable functions in high-diversity ecosystems. PLoS Biol. 11:e1001569. doi: 10.1371/journal.pbio.1001569

Naiman, R. J., Décamps, H., McClain, M. E., and Likens, G. E. (2005). "6 - biophysical connectivity and riparian functions," in Riparia: Ecology, Conservation, and Management of Streamside Communities, ed. R. J. N. D. E. M. E. Likens (Burlington, NJ: Academic Press), 159-187. doi: 10.1016/b978-012663315-3/50007-1

Nakagawa, M., Ushio, M., Kume, T., and Nakashizuka, T. (2019). Seasonal and long-term patterns in litterfall in a Bornean tropical rainforest. Ecol. Res. 34, 31-39. doi: 10.1111/1440-1703.1003

National Institute of Meteorology (1981-2010). INMET Climatological Normal 1981-2010. Available online at: https://clima.inmet.gov.br/ GraficosClimatologicos/DF/83377 (accessed March 1, 2021).

Neres-Lima, V., Machado-Silva, F., Baptista, D. F., Oliveira, R. B. S., Andrade, P. M., Oliveira, A. F., et al. (2017). Allochthonous and autochthonous carbon flows in food webs of tropical forest streams. Freshw. Biol. 62, 1012-1023. doi: 10.1111/fwb.12921

Niinemets, Ü, and Tamm, Ü (2005). Species differences in timing of leaf fall and foliage chemistry modify nutrient resorption efficiency in deciduous temperate forest stands. Tree Physiol. 25, 1001-1014. doi: 10.1093/treephys/25.8.1001

Oksanen, J., Blanchet, F. G., Friendly, M., Kindt, R., Legendre, P., McGlinn, D., et al. (2020). vegan: Community Ecology Package. R package version 2.5-7. Available online at: https://CRAN.R-project.org/package=vegan

Oliveira-Filho, A., Ratter, J. A., Oliveira, P. S., and Marquis, R. J. (2002). "Vegetation physiognomies and woody flora of the cerrado biome," in The Cerrados of Brazil: Ecology and Natural History of a Neo-Tropical Savanna, eds P. S. Oliveira and R. J. Marquis (New York City, NY: Columbia University Press), doi: 10.7312/OLIV12042-005 
Ott, D., Rall, B. C., and Brose, U. (2012). Climate change effects on macrofaunal litter decomposition: the interplay of temperature, body masses and stoichiometry. Philos. Trans. R. Soc. B Biol. Sci. 367, 3025-3032. doi: 10. 1098/rstb.2012.0240

Panchen, Z. A., Primack, R. B., Gallinat, A. S., Nordt, B., Stevens, A.-D., Du, Y., et al. (2015). Substantial variation in leaf senescence times among 1360 temperate woody plant species: implications for phenology and ecosystem processes. Ann. Bot. 116, 865-873. doi: 10.1093/aob/mcv015

Pinheiro, J., Bates, D., DebRoy, S., Sarkar, D., and R Core Team (2020). nlme: Linear and Nonlinear Mixed Effects Models. R package version 3.1-150. Available online at: https://CRAN.R-project.org/package $=$ nlme

Prescott, C. E. (2002). The influence of the forest canopy on nutrient cycling. Tree Physiol. 22, 1193-1200. doi: 10.1093/treephys/22.15-16.1193

R Core Team (2020). R: A Language and Environment for Statistical Computing. R version 4.0.1. Vienna: R Foundation for Statistical Computing.

Raymond, P. A., Hartmann, J., Lauerwald, R., Sobek, S., McDonald, C., Hoover, M., et al. (2013). Global carbon dioxide emissions from inland waters. Nature 503, 355-359.

Reich, P. B. (1995). Phenology of tropical forests: patterns, causes, and consequences. Can. J. Bot. 73, 164-174. doi: 10.1139/b95-020

Reich, P. B., and Borchert, R. (1984). Water stress and tree phenology in a tropical dry forest in the lowlands of Costa Rica. J. Ecol 72, 61-74. doi: 10.2307/2260006

Serrano, L. (1992). "Leaching from vegetation of soluble polyphenolic compounds, and their abundance in temporary ponds in the Doñana National Park (SW Spain)," in Dissolved Organic Matter in Lacustrine Ecosystems: Energy Source and System Regulator Developments in Hydrobiology, eds K. Salonen, T. Kairesalo, and R. I. Jones (Dordrecht: Springer Netherlands), 43-50. doi: 10.1007/978-94-011-2474-4_3

Tang, J., Körner, C., Muraoka, H., Piao, S., Shen, M., Thackeray, S. J., et al. (2016). Emerging opportunities and challenges in phenology: a review. Ecosphere 7:e01436. doi: 10.1002/ecs2.1436

Tharayil, N., Suseela, V., Triebwasser, D. J., Preston, C. M., Gerard, P. D., and Dukes, J. S. (2011). Changes in the structural composition and reactivity of Acer rubrum leaf litter tannins exposed to warming and altered precipitation: climatic stress-induced tannins are more reactive. New Phytol. 191, 132-145. doi: 10.1111/j.1469-8137.2011.03667.x

Tiegs, S. D., Costello, D. M., Isken, M. W., Woodward, G., McIntyre, P. B., Gessner, M. O., et al. (2019). Global patterns and drivers of ecosystem functioning in rivers and riparian zones. Sci. Adv. 5:eaav0486. doi: 10.1126/sciadv.aav0486

Tonin, A. M., Boyero, L., Bambi, P., Pearson, R. G., Correa-Araneda, F., and Gonçalves, F. G. Jr. (2019). High within-stream replication is needed to predict litter fluxes in wet-dry tropical streams. Freshw. Biol 65, 688-697. doi: 10.1111/ fwb. 13459
Tonin, A. M., Gonçalves, J. F., Bambi, P., Couceiro, S. R. M., Feitoza, L. A. M., Fontana, L. E., et al. (2017). Plant litter dynamics in the forest-stream interface: precipitation is a major control across tropical biomes. Sci. Rep. 7:10799. doi: 10.1038/s41598-017-10576-8

Wallace, J. B., Eggert, S. L., Meyer, J. L., and Webster, J. R. (1997). Multiple trophic levels of a forest stream linked to terrestrial litter inputs. Science 277, 102-104. doi: $10.1126 /$ science.277.5322.102

Webster, J. R., Benfield, E. F., Ehrman, T. P., Schaeffer, M. A., Tank, J. L., Hutchens, J. J., et al. (1999). What happens to allochthonous material that falls into streams? A synthesis of new and published information from Coweeta. Freshw. Biol. 41, 687-705. doi: 10.1046/j.1365-2427.1999.00409.x

Wickham, H. (2016). ggplot2: Elegant Graphics for Data Analysis, 2nd Edn. (Springer-Verlag, New York).

Wickham, H., Averick, M., Bryan, J., Chang, W., McGowan, L. D., François, R., et al. (2019). Welcome to the tidyverse. J. Open Source Softw. 4:1686. doi: 10.21105 /joss.01686

Wood, S. N. (2011). Fast stable restricted maximum likelihood and marginal likelihood estimation of semiparametric generalized linear models. J. R. Stat. Soc. Ser. B Stat. Methodol. 73, 3-36. doi: 10.1111/j.1467-9868.2010.00749.x

Wright, S. J. (1996). "Plant species diversity and ecosystem functioning in tropical forests," in Biodiversity and Ecosystem Processes in Tropical Forests Ecological Studies, eds G. H. Orians, R. Dirzo, and J. H. Cushman (Berlin: Springer), 11-31. doi: 10.1007/978-3-642-79755-2_2

Zhang, H., Yuan, W., Dong, W., and Liu, S. (2014). Seasonal patterns of litterfall in forest ecosystem worldwide. Ecol. Complex. 20, 240-247. doi: 10.1016/j.ecocom. 2014.01.003

Zuur, A., and Ieno, E. N. (2015). A Beginner's Guide to Data Exploration and Visualisation with R. Newburgh: Highland Statistics Ltd.

Zuur, A., Ieno, E. N., Walker, N., Saveliev, A. A., and Smith, G. M. (2009). Mixed Effects Models and Extensions in Ecology With R. Berlin: Springer Science \& Business Media.

Conflict of Interest: The authors declare that the research was conducted in the absence of any commercial or financial relationships that could be construed as a potential conflict of interest.

Copyright (c) 2021 Tonin, Lima, Bambi, Figueiredo, Rezende and Gonçalves. This is an open-access article distributed under the terms of the Creative Commons Attribution License (CC BY). The use, distribution or reproduction in other forums is permitted, provided the original author(s) and the copyright owner(s) are credited and that the original publication in this journal is cited, in accordance with accepted academic practice. No use, distribution or reproduction is permitted which does not comply with these terms. 